\title{
Review Article \\ Peripheral Pathways in the Food-Intake Control towards the Adipose-Intestinal Missing Link
}

\author{
Hugo Mendieta Zerón, ${ }^{1,2}$ Ma. Victoria Domínguez García,' \\ María del Socorro Camarillo Romero, ${ }^{1}$ and Miriam V. Flores-Merino ${ }^{1}$ \\ ${ }^{1}$ Medical Sciences Research Center (CICMED), Autonomous University of the State of Mexico (UAEMex), 50170 Toluca, Mexico
${ }^{2}$ Asociación Científica Latina (ASCILA) and Ciprés Grupo Médico (CGM), Felipe Villanueva sur 1209 Col. Rancho Dolores Z.C.,
50170 Toluca, Mexico
}

Correspondence should be addressed to Hugo Mendieta Zerón; mezh_74@yahoo.com

Received 26 March 2013; Accepted 16 October 2013

Academic Editor: Paolo de Girolamo

Copyright ( 2013 Hugo Mendieta Zerón et al. This is an open access article distributed under the Creative Commons Attribution License, which permits unrestricted use, distribution, and reproduction in any medium, provided the original work is properly cited.

In the physiological state a multitude of gut hormones are released into the circulation at the same time depending on the quality and quantity of the diet. These hormones interact with receptors at various points in the "gut-brain axis" to affect short-term and intermediate-term feelings of hunger and satiety. The combined effects of macronutrients on the predominant gut hormone secretion are still poorly understood. Besides, adipokines form an important part of an "adipoinsular axis" dysregulation which may contribute to $\beta$-cell failure and hence to type 2 diabetes mellitus (T2DM). Even more, gestational diabetes mellitus (GDM) and T2DM seem to share a genetic basis. In susceptible individuals, chronic exaggerated stimulation of the proximal gut with fat and carbohydrates may induce overproduction of an unknown factor that causes impairment of incretin production and/or action, leading to insufficient or untimely production of insulin, so that glucose intolerance develops. The bypass of the duodenum and jejunum might avoid a putative hormone overproduction in the proximal foregut in diabetic patients that might counteract the action of insulin, while the early presentation of undigested or incompletely digested food to the ileum may anticipate the production of hormones such as GLP1, further improving insulin action.

\section{Introduction}

Under steady-state conditions, all ingested fuels (energy intake) are normally metabolized to maintain basic metabolic rate, thermogenesis, and muscle action (energy expenditure). Food intake and energy expenditure can be influenced by environment and lifestyle. This knowledge highlights the importance of understanding the physiological and molecular mechanisms responsible for the final predominated signal of appetite control [1].

All of the peripheral and central processes that make up this highly complex system are subject to individual predisposition through genes. Key peripheral components are the gustatory system, the gastrointestinal tract, pancreas, liver, muscle, and adipose tissue (Figure 1). The aim of this review is to give an insight into the major peripheral signals in the food intake control, viewed in a dynamic context taking into account the major food related signals and to discern possible explanations of the diabetogenic state recovery after weight lose [2].

\section{Intestinal Signals}

Over 30 different regulatory peptide hormones are secreted in the gut, the largest endocrine organ in the body. Gut nutrient content stimulates several of these hormones which interact with receptors at various points in the "gut-brain axis" to affect short-term and intermediate-term feelings of hunger and satiety [3]. The major gut hormones implicated in appetite control (Table 1) are age, sex, and body mass index (BMI) dependent (Table 2).

By chemo/mechanosensory mechanisms, the gastrointestinal tract sends information to the brain regarding 
TABLE 1: Major peripheral signals involved in food intake regulation.

\begin{tabular}{|c|c|c|c|c|}
\hline & Hormone & Site of secretion & Major receptors & Major actions \\
\hline \multirow{8}{*}{ Intestinal } & Amylin & Pancreatic $\beta$ cells & $\mathrm{AMY}_{1-3}$ & $\begin{array}{l}\text { Inhibits gastric secretion } \\
\text { Delays gastric emptying } \\
\text { Decreases blood glucose }\end{array}$ \\
\hline & Cholecystokinin & Intestinal Icells & CCK2 & $\begin{array}{c}\text { Gall bladder contraction } \\
\text { Delays gastric emptying } \\
\text { Pancreatic enzyme contraction }\end{array}$ \\
\hline & Endocannabinoid system & Postsynaptic cell & $\mathrm{CB} 1, \mathrm{CB} 2$ & $\begin{array}{l}\text { Modulates appetite besides a variety of } \\
\text { physiological processes }\end{array}$ \\
\hline & Ghrelin & Gastric fundal A cells & GHS-R & $\begin{array}{l}\text { Increases gastric motility } \\
\text { Growth of hormone release }\end{array}$ \\
\hline & Glucagon & Pancreatic $\alpha$ cells & Glucagon & $\begin{array}{l}\text { Gluconeogenesis } \\
\text { Glycogenolysis }\end{array}$ \\
\hline & $\begin{array}{l}\text { Glucagon-like peptide-1 } \\
\text { (GLP-1) }\end{array}$ & Gastrointestinal L cells & GLP-1 & $\begin{array}{c}\text { Glucose-dependent insulin release } \\
\text { Delays gastric emptying } \\
\text { Vagal and CNS effects }\end{array}$ \\
\hline & $\begin{array}{c}\text { Glucose-dependent } \\
\text { insulinotropic polypeptide } \\
\text { (GIP) }\end{array}$ & $\begin{array}{l}\text { K cells in duodenum and } \\
\text { jejunum }\end{array}$ & GIP-R & Stimulates insulin synthesis and secretion \\
\hline & Oxyntomodulin & Gastrointestinal L cells & GLP-1 & $\begin{array}{c}\text { Glucose-dependent insulin release } \\
\text { Delays gastric emptying } \\
\text { Vagal and CNS effects }\end{array}$ \\
\hline \multirow{6}{*}{ Adipose } & Pancreatic polypeptide & Pancreatic PP cells & $\mathrm{Y}_{4}$ & Delays gastric emptying \\
\hline & Peptide YY (PYY) & Gastrointestinal L cells & $\mathrm{Y}_{2}$ & $\begin{array}{l}\text { Delays gastric emptying } \\
\text { Vagal and CNS effects }\end{array}$ \\
\hline & Adiponectin & $\begin{array}{c}\text { Adipocyte, } \\
\text { skeletal muscle, } \\
\text { endothelial cells, and } \\
\text { cardiomyocytes }\end{array}$ & $\begin{array}{l}\text { AdipoR1 } \\
\text { AdipoR2 } \\
\text { T-cadherin }\end{array}$ & $\begin{array}{l}\text { Adiponectin, via AMPK } \\
\text { phosphorylation, increases insulin } \\
\text { sensitivity, fatty acid oxidation and } \\
\text { reduces the synthesis of glucose in the } \\
\text { liver and other tissues }\end{array}$ \\
\hline & Leptin & Adipocyte & LEPR & $\begin{array}{l}\text { Increases POMC anorexigenic signals } \\
\text { Inhibits NPY, stimulating appetite }\end{array}$ \\
\hline & $\begin{array}{l}\text { Plasminogen activator } \\
\text { inhibitor-1 (PAI-1) }\end{array}$ & Endothelium, adipocyte & Binds to (tPA) & Inhibitor of fibrinolysis \\
\hline & $\begin{array}{l}\text { Tumour necrosis factor } \\
\text { alpha (TNF- } \alpha)\end{array}$ & Adipocyte & $\begin{array}{l}\text { Tumor necrosis factor } \\
\text { receptor (TNFR) }\end{array}$ & Insulin resistance \\
\hline
\end{tabular}

AMPK: AMP-activated protein kinase, CNS: central nervous system, NPY: neuropeptide Y, POMC: proopiomelanocortin, and tPA: tissue plasminogen activator.

available energy for metabolism. Postprandially, activation of gut mechanoreceptors, changes in circulating nutrient concentration, and release of anorectic gut hormones all lead to a reduction in subsequent feeding [4]. However, apart from traditional homeostatic feedback regulation of energy balance, food appearance, flavor, and availability in addition to social, cultural, and economic influences determine food intake. Importantly, there is also modulation of food intake by hedonic and mnemonic neuronal circuits [5]. The modern consensus is, therefore, that there is interaction between homeostatic and nonhomeostatic inputs, which together lead to coordination in terms of inducing either an orexigenic or anorectic response.

2.1. Amylin. Amylin or islet amyloid polypeptide (IAPP) is a 37-amino acid pancreatic peptide that is cosecreted with insulin. This hormone is a member of the calcitonin family of peptides and is involved in meal satiety signaling [6-8]. As such, amylin and related compounds also inhibit gastric emptying and reduce meal size $[9,10]$.

Synthetic or naturally occurring amylin agonists have been shown to be more potent and have a longer duration of feeding suppression than amylin itself [11]; one such potent anorectic analog in humans, primates, and rodents is calcitonin of salmon origin (sCT) [12]. This compound irreversibly binds to amylin receptors to produce sustained anorectic responses [13]. Additionally, the anorectic potency of amylin agonists is not dependent on intact vagal afferent signaling [14].

2.2. Cholecystokinin. Cholecystokinin (CCK) is considered a highly selective satiation signal acting over two receptors, the CCK-B, predominantly found in the brain, where the unsulfated tetrapetide CCK- 4 is active and the A-type 


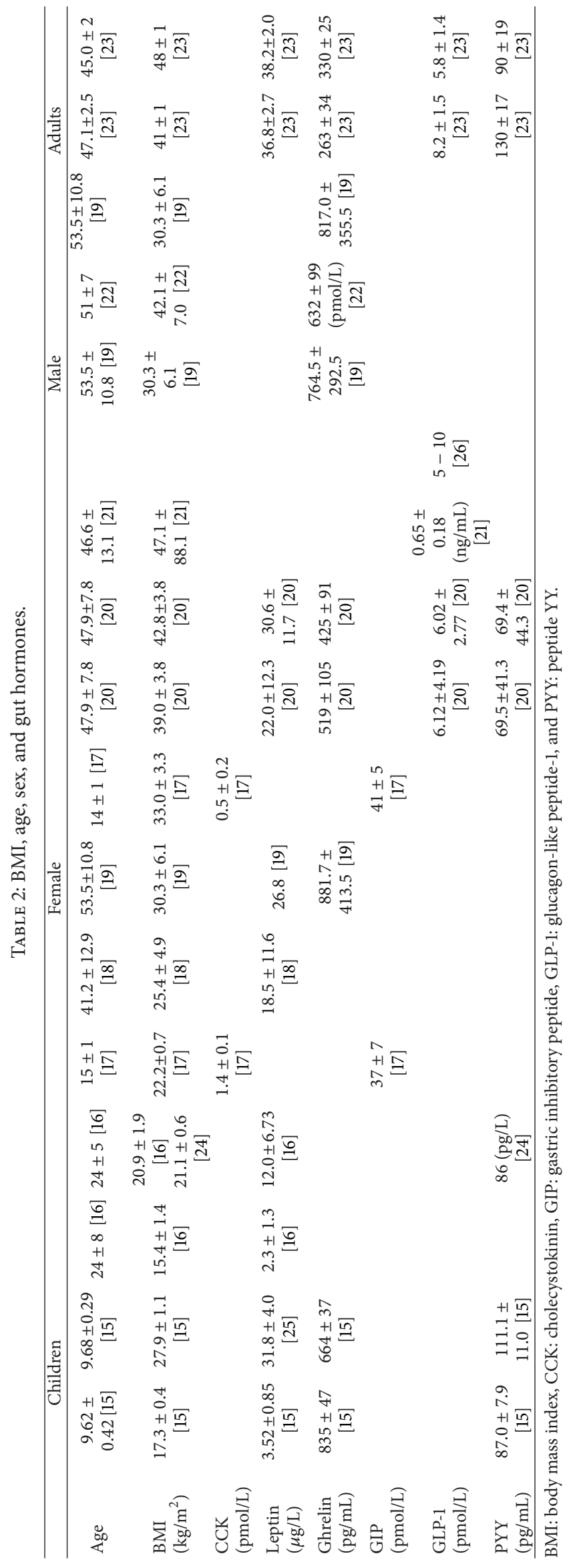




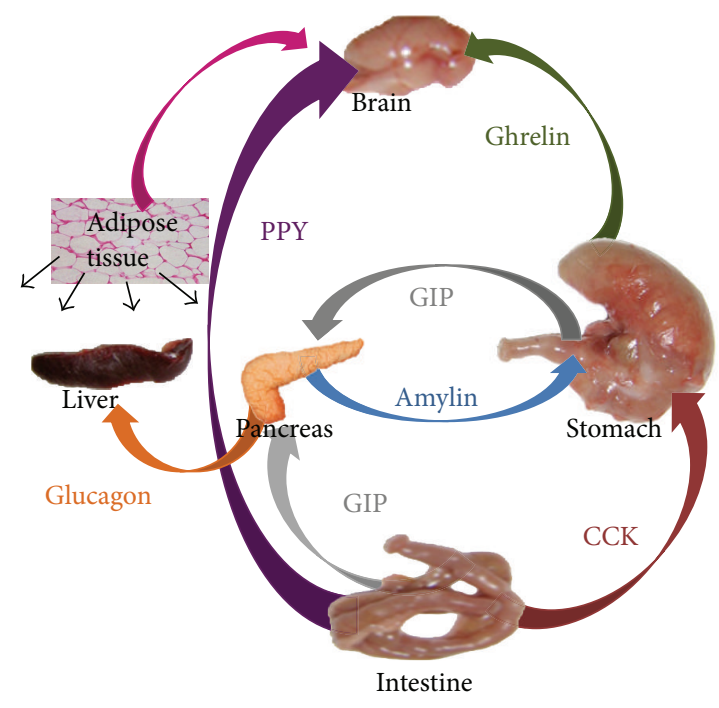

FIGURE 1: Interacting hormones involved in food-intake control. GIP: glucose-dependent insulinotropic polypeptide; PYY: peptide YY.

receptor of the gastrointestinal tract, where the sulfated CCK-forms (CCK-8-S, CCK-33-S, CCK-39-S, and CCK-58$S)$ bind. Satiety and meal size limitation are mediated mainly by the CCK-A-receptor [27].

Luminal fat and protein are strong releasers of CCK from enteroendocrine cells. The food intake suppressive effect results from CCK acting in a paracrine fashion on CCKA receptors located on vagal sensory nerve terminals in the mucosal lamina propia [28-30]. Intact vagal afferent neurons are required for the satiety effects of CCK.

2.3. Endocannabinoid System. There are reports suggesting that the peripheral endocannabinoid system is implicated in the regulation of energy balance. For instance, during periods of fasting, levels of the endocannabinoid and anandamide are elevated in the rat duodenum [31]. Furthermore, in obese rodents, an increase in mRNA for CB1 receptors is observed in the stomach [32] and in the nodose ganglia [33], and endocannabinoid levels in the duodenum, pancreas, and liver are similarly elevated in this animal model [34]. On the contrary, cannabinoid CB1 receptor antagonists reduce food intake and body weight, but clinical use in humans has been limited by effects on the central nervous system (CNS), although there are new options with limited CNS penetration [35].

2.4. Ghrelin. Ghrelin is an orexigenic hormone [36], secreted in the oxyntic gland cells in the mucosa of the stomach, originally isolated from the rat stomach as an endogenous ligand of the growth hormone secretagogue receptor (GHS$\mathrm{R}$ ), and has been shown to have a GH-releasing effect [37]. Yet, the ghrelin receptor is expressed by a subset of stomach innervating vagal afferent neurons in the nodose ganglia [38].

Plasma ghrelin concentrations are elevated during a fast. Moreover, plasma ghrelin concentrations display a circadian rhythm: a rise before each meal and a rapid fall after eating.
Fasting morning ghrelin concentrations have a negative correlation with fat mass index [39]. On the other hand, dietinduced weight loss in obese individuals increased plasma ghrelin levels [40]. These findings suggest that plasma ghrelin levels may represent a compensatory response to altered energy metabolism. Of note, central and peripheral administration of ghrelin stimulates food intake and body weight gain [37].

2.5. Glucose-Dependent Insulinotropic Polypeptide (GIP). Glucose-dependent insulinotropic polypeptide (GIP) is manufactured and released in the duodenum and proximal jejunum by the $\mathrm{K}$ cells. Its plasma concentration increases quickly following food ingestion, stimulating an increase in insulin synthesis and secretion [41]. Carbohydrate, fat, and protein have all been shown to stimulate GIP secretion [42]. Pancreatic and duodenal homeobox-1 (Pdx-1) binds to GIP promoter. This, together with the fact of a remarkable reduction in the number of GIP-expressing cells in Pdx-/mice [43], suggests that this incretin may play a role in $\beta$-cell differentiation.

2.6. Glucagon-Like Peptide-1 (GLP-1). Proglucagon is a 160amino acid prohormone that is produced in the $\alpha$ cells of the pancreatic islets, the $\mathrm{L}$ cells of the distal gut, and within the CNS. Selective posttranslational proteolysis of proglucagon by prohormone convertases 1 and 2 results in the tissue-specific production of a number of biologically active fragments.

GLP-1 is a potent insulin secretagogue that is secreted, in response to ingested nutrients. GLP-1 and related agonists, such as exendin-4, have been demonstrated to reduce food intake by slowing gastric emptying, reducing meal size, and promoting feelings of satiety $[44,45]$. The reductions in food intake by these compounds appear to be peripherally mediated, as they are dependent on intact vagal afferent signaling [46]. The importance of the vagus nerve in mediating the proximal-distal loop was elucidated from the evidence that GLP-1 secretion is enhanced when the fat is administered into the duodenum or when the GLP-1 secretion, in response to the infusion of physiological concentration of GIP, was completely abrogated by vagotomy [47].

2.7. Oxyntomodulin. Another product of the tissue-specific differential cleavage of proglucagon is oxyntomodulin

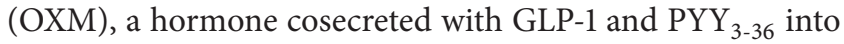
the circulation by intestinal L-cells after nutrient ingestion [48]. OXM is a satiety signal through GLP-1R $[36,49]$ and administration reduces energy intake in both rodents and humans [50, 51]. OXM levels are increased after gastric bypass surgery.

2.8. PYY. PYY is a 36-amino acid peptide, which belongs to the pancreatic polypeptide (PP) family, which also includes NPY. All these bind to G-protein coupled receptors $\mathrm{Y}_{1}, \mathrm{Y}_{2}, \mathrm{Y}_{4}$, $\mathrm{Y}_{5}$, and $\mathrm{Y}_{6}$, displaying promiscuity in their interactions with these receptors by virtue of their shared hair-pin-fold motif structure [3]. 
PYY is produced by the L cells of the gut, with highest concentrations found in the large bowel and the rectum [52]. Two endogenous forms, $\mathrm{PYY}_{1-36}$ and $\mathrm{PYY}_{3-36}$, are released postprandially into the circulation. $\mathrm{PYY}_{3-36}$, which acts mainly via the $\mathrm{Y}_{2}$ receptor, is further produced by cleavage of the Tyr-Pro amino terminal residues of PYY ${ }_{1-36}$ by the enzyme dipeptidyl peptidase IV (DPP-IV). PYY 1-36 predominates in the circulation in the fasted state, whereas $\mathrm{PYY}_{3-36}$ is the major circulating form postprandially. Following a meal, circulating levels of $\mathrm{PYY}_{3-36}$ rise within $15 \mathrm{~min}$, peak at approximately $90 \mathrm{~min}$ and remain elevated for up to 6 hours [53]. The magnitude of the rise in $\mathrm{PYY}_{3-36}$ is in proportion to the calories ingested [54]. When exogenously administered intravenously, its circulating half-life is approximately $8 \mathrm{~min}$ [43].

Initial postprandial release of $\mathrm{PYY}_{3-36}$ is likely to be under neural control, and further release of $\mathrm{PYY}_{3-36}$ is observed when the nutrients arrive in the distal gut, particularly stimulated by a high fat diet [55]. The protein content of the diet is thought to be influential for delayed $\mathrm{PYY}_{3-36}$ release approximately 2 hours postprandially [56]. Besides a direct central action, $\mathrm{PYY}_{3-36}$ is likely to affect appetite via its effects on gut motility, leading to a sensation of fullness and satiety [57].

\section{Adipose Signals}

Adipokines form an important part of an "adipoinsular axis," dysregulation of which may contribute to $\beta$-cell failure and hence to T2DM. While some adipokines have beneficial effects, others have detrimental properties depending on the predominant intracellular signalling pathways [58]. The major cause of T2DM could be a human metabolic zwitterion-like molecule, with positive or negative effects over the beta cell depending on its state of activation.

3.1. Adiponectin. Unlike many other adipokines, adiponectin has beneficial effects improving insulin sensitivity and vascular function, thus being both antidiabetic [59] and antiatherogenic [60]. Opposite to other adipokines the circulating levels are decreased when the BMI is higher. The loss in body weight by adiponectin is mainly due to stimulation of energy expenditure [61].

Two adiponectin receptors AdipoR1 and AdipoR2 that exhibit $67 \%$ homology have been cloned. Many of the effects of the adiponectin-AdipoR interaction have been suggested to be mediated by $5^{\prime}$ AMP-activated protein kinase (AMPK), peroxisome proliferator-activated receptor a (PPARa), and p38 mitogen-activated protein kinases (MAPK) [62].

3.2. Leptin. Leptin is thought to signal longer-term energy status. This hormone engages a number of intracellular pathways, including those associated with cyclic adenosine monophosphate (cAMP), MAPK, phosphatidylinositol 3'kinase (PI3 K), and signal transducer and activator of transcription 3 (STAT3) $[63,64]$.

In contrast to adiponectin, serum concentration of circulating leptin is elevated in obesity. Thus, probably there is a decrease in response to leptin [61]. Although leptin showed a great potential in preclinical studies, it was usefulness in clinical trials [65]. In eating disorders the results are controversial [66].

In the hypothalamic arcuate nucleus there are two types of neuronal populations with high levels of expression of the leptin receptor (LEPR), proopiomelanocortin (POMC), and cocaine- and amphetamine-regulated transcript (CART) neurons, which activate anorexigenic pathways $[67,68]$ and agouti-related peptide (AGRP) and neuropeptide Y (NPY) neurons that transfer appetite stimulating signals. A decrease in leptin is correlated with an increased food intake [67].

By binding to LEPR in the hypothalamus, leptin causes Janus kinase 2 (JAK2) activation and LEPR tyrosine residues phosphorylation, allowing STAT3 to be dimerized and translocated to the nucleus, leading to anorectic peptide synthesis $[67,68]$. Also, it has been shown that leptin's effects on food intake and body weight require inhibition of hypothalamic AMPK. Thus, hypothalamic AMPK plays a critical role in hormonal and nutrient-derived anorexigenic and orexigenic signals and in energy balance $[69,70]$.

3.3. Plasminogen Activator Inhibitor-1 (PAI-1). Plasminogen activator inhibitor-1 (PAI-1) is the most important endogenous inhibitor of fibrinolysis and increased levels are associated with insulin resistance, body weight control, and thrombosis. In humans, visceral adipose mass has been shown to be a primary determinant of PAI-1 levels. In T2DM, not only increased adipose tissue mass but other metabolic disturbances, including hyperinsulinemia, hyperglycemia, and dyslipidemia, alter adipose tissue function and lead to increased production and circulating levels of PAI-1 [25]. Consumption of fructose at $25 \%$ of energy requirements for 10 weeks leads to increases of fasting as well as postprandial PAI-1, suggesting the possibility that prolonged consumption of fructose may contribute to the development of metabolic syndrome via induction of prothrombotic (PAI-1) mediators besides proinflammatory cytokines [71].

\section{Combined Signals}

In the fed physiological state a multitude of gut hormones are released into the circulation at the same time depending on the quality and quantity of the diet with recommended proportions of the macronutrients as follows: carbohydrates 60\%, proteins: $20 \%$, and lipids: $20 \%$ (Figure 2). How the satiety factors act in concert to regulate appetite is still misunderstood.

Following the above-mentioned idea, after a high-protein meal, ghrelin declines gradually in both normal weight and obese children without subsequent increase, whereas ghrelin is suppressed more rapidly to a nadir at $60 \mathrm{~min}$ after a highcarbohydrate meal in both groups of children, followed by rebound in ghrelin levels. Similarly, after the high-protein meal, PYY concentrations increase steadily over the course of the morning in both groups without decline, whereas PYY levels peaked $30 \mathrm{~min}$ after the high-carbohydrate meal in both normal weight and obese subjects with significant 


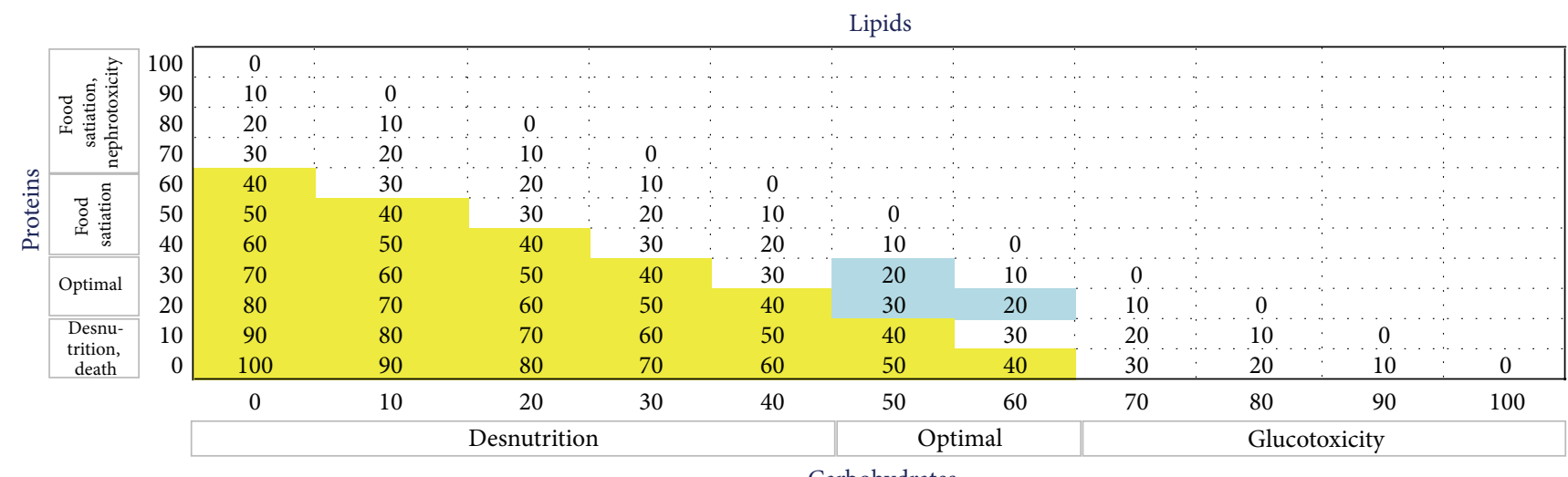

Carbohydrates

Lipotoxicity

Recommended proportions for metabolic equilibrium

FIGURE 2: Recommended proportions of macronutrients.

decline thereafter. Ghrelin and PYY responses to the high-fat meal are somewhat intermediate between that observed with high carbohydrate and high protein [15].

Amylin, especially when combined with other anorectic hormones, has beneficial long-term effects on body weight. For example, amylin and GLP-1 mediate the feedback control of eating by seemingly separate but overlapping mechanisms. Another case is CCK, a synergic effect has been observed when applied simultaneously with amylin, estradiol, insulin, and leptin [72].

The combination of $\mathrm{PYY}_{3-36}$ and GLP-17-36 amide produces a reduction in ad libitum energy intake in healthy, lean human subjects [73]. Recent work in investigating the utility of combinational therapies for the treatment of obesity has focused on the coadministration of amylin with leptin [74]. Moreover, combinational therapy of exendine- $4+$ sCT produced sustained daily food reductions without tolerance, nausea, malaise, or rebound feeding. These findings further support the view that engaging multiple feeding inhibitory pathways to reduce food intake could be a potential strategy for the treatment of obesity.

\section{Peripheral Signals Modulated by Food}

One strategy for the prevention of overweight and obesity related diseases is the use of agents that interfere with the hydrolysis and absorption of dietary carbohydrates and lipids. The most important dietary carbohydrates are starch, sucrose, and lactose. They are digested by disaccharidases in the upper gastrointestinal tract and broken down into monosaccharides. Subsequently they are absorbed to the circulation. The elevated glucose concentration in blood promotes insulin secretion from the $\beta$ cells of the islets of Langerhans in the pancreas, and insulin mediates the uptake of glucose in peripheral tissues including muscle, adipose tissue, and kidney. Taking into account the importance of carbohydrate metabolism, the gastrointestinal enzymes can be therapeutic targets for limiting absorption of monosaccharides [75].
In addition, the most important dietary lipids are triglycerides and cholesterol esters. They are digested by pancreatic lipase and pancreatic phospholipase A2 to glycerol, fatty acids, and free cholesterol. Finally, they are absorbed to the circulation and may be used or stored in adipose tissue [76].

In the literature it can be found several reviews that describe active substances in plants that inhibit pancreatic enzymes. It has been recorded that more than 1200 plant species could have a hypoglycemic activity [77]. For example, Hanhineva et al. revised the inhibitory properties of polyphenols (i.e. flavonoids, phenolic acids, proanthocyanidins, and resveratrol). They reported that these polyphenols may influence carbohydrate metabolism at many levels. More interesting is that these compounds are contained in plantbased foods, such as tea, coffee, wine, cocoa, cereal grains, soy, fruits, and berries $[78,79]$.

Besides the food in their natural form, the heat processing of food (i.e., boiling) can produce derivate compounds that show digestive enzymes inhibitory properties. For example, it has been shown that after heat treating of raw ginseng, amino acid derivatives such as arginyl-fructose and arginylfructosyl-glucose are formed at high levels; these products inhibited postprandial hyperglycemia through the inhibition of $\alpha$-amylase and $\alpha$-glucosidase [80]. Other compounds such as flavonoids from grape seed Cat's whiskers and Sweetleaf extract obtained by heat processing also inhibited $\alpha$-amylase [81].

It is worth mentioning that some plants do not show a significant effect in the inhibition of $\alpha$-amylase; however, in combination with acarbose, an antidiabetic drug with $\alpha$-glucosidase inhibitory properties has a synergistic effect due to low doses of acarbose that are necessary for the postprandial glycemic control. For example, the polyphenol extracts from a range of berries, especially raspberry and rowanberry, showed an effect only in combination with acarbose [82]. Other examples of this synergistic action are the inhibition by cyanidin-3-rutinoside [83] and some species of cinnamon [84]. 
The brush border enzymes are inhibited by molecules extracted from plants. For example, the D-fagomine from seeds of buckwheat inhibits sucrase [85], diacylated anthocyanin from purple sweet potatoes has been shown to inhibit maltase [86], cyanidin-3-galactoside inhibits sucrase and maltase [87], and $\alpha$-glucosidase is inhibited by the hydromethanolic seed extract of Holarrhena antidysenterica [88], by ethanol extract of the fruit case of Garcinia mangostan [89], and by Corni fructus [90]. Flavonoids from grape seed Cat's whiskers and Sweetleaf extract inhibit intestinal sucrase and maltase [81] (which is also inhibited by some species of cinnamon) [84].

Enzymes from the metabolism of lipids can be also inhibited by compounds of the plants; for example, oligomeric procyanidins in the apple polyphenol extract inhibit pancreatic lipase [91], and arginyl-fructose and arginyl-fructosylglucose inhibit lipase [80]. Cocoa procyanidins inhibit pancreatic lipase, also pancreatic $\alpha$-amylase, and phospholipase $\mathrm{A} 2$, and this inhibition produces a decrement in plasma triglyceride and glucose concentrations in mice as well as humans [92].

More studies are needed about the inhibitory activity of substances from natural origins (i.e., plants) on intestinal enzymes. Diabetic patients would beneficiate if they include these plants in their diet instead of active purified compounds. However, the concentrations in food of the active complexes could be not enough, then it is essential to get them in a purify form. For this reason, studies are needed in this area.

\section{Evidence for the Existence of an Intestinal Missing Link}

6.1. Gestational Diabetes Mellitus. Obesity increases the risks of gestational diabetes mellitus (GDM) [93, 94]. Even more, there seems to be a shared genetic basis between GDM and T2DM [95]. In fact, the diagnosis of GDM identifies patients with a pancreatic $\beta$-cell defect. In some patients, the defect is transient or stable, but in most it is progressive, imparting a high risk of diabetes for at least a decade after the index pregnancy.

The majority of women with GDM have clinical characteristics indicating a risk for T2DM. Available evidence indicates that T2DM can be prevented or delayed by intensive lifestyle modification and by medications, particularly those that ameliorate insulin resistance. All patients should be monitored for rising glycemia indicative of progressive $\beta$ cell deterioration. Monitoring should be initiated at least annually and should be intensified if glycemia is rising and/or impaired.

Like monitoring, lifestyle modification for obese and overweight women during pregnancy should be intensified for rising glycemia and/or development of impaired glucose levels. These measures restrict gestational weight gain and reduce the prevalence of gestational diabetes [96].

6.2. Obesity and Diabetes. Obesity, a BMI greater than $30 \mathrm{~kg} / \mathrm{m}^{2}$, is strongly and causally linked to T2DM. Recent data suggest that the prevention of diabetes is feasible if weight management is addressed. Modest weight loss of 5$10 \%$ body weight is known to improve diabetes by reducing insulin resistance in obese individuals [97]. Regarding this strategy, in clinical trials, caloric restriction, exercise, and weight loss have been shown to prevent and reduce diabetes in obese individuals $[97,98]$ in part by attenuating insulin resistance and subsequent hyperinsulinemia, thereby preserving $\beta$-cell function $[99,100]$.

While the goal of a cure for T2DM remains some way off, bariatric surgery has long been proven to be effective in weight reduction in the morbidly obese, as well as in maintaining long-term weight reduction. With this weight reduction, obesity-related comorbidities, including T2DM, tend to improve or resolve completely.

6.3. Bariatric Surgery. Bariatric surgery promotes effective and sustained weight loss in morbidly obese subjects [101]. Since 1991, several medical societies have established the criteria for bariatric surgery in cases with BMI $>40$ or BMI $>35$ with serious comorbidities [102].

Depending on the type of bariatric procedure, up to $80 \%$ resolution of T2DM has been reported, being more effective that those techniques that bypass the foregut like the Roux en-Y gastric bypass (RYGBP) [103-106]. Being more specific, Sugerman et al. found that a young age was a positive predictor for T2DM resolution [107] as well as early surgery that preempts irreversible pancreatic $\beta$-cell deterioration [108].

There are two different theories proposed to explain the laboratorial benefits after bariatric surgery. The hindgut theory by Cummings et al. [109] proposes that the rapid transit of nutrients to the hindgut improves glucose metabolism, probably through GLP-1. The second hypothesis, the foregut theory by Rubino [110], says that the exclusion of the foregut from the food stream causes a decrease in insulin resistance through the secretin pathway. The two theories are not mutually exclusive.

RYGBP causes an improvement in a diabetic patient's status through a variety of mechanisms. More interestingly, improvement often occurs very soon after the bypass, even before significant weight loss has occurred [111, 112]. First and foremost, RYGBP enforces severe calorie restriction through both mechanical restriction and the upregulation of satiety signals such as anorexigen PYY [113]. The decrease in caloric intake is by itself able to result in the improvement of T2DM [114].

One possible explanation for the metabolic improvement after RYGBP hypothesis is that bariatric surgeries with gastric bypass exclude the site responsible for the production of the hormone causing T2DM [115]. Other explanations are possible. For example, a hormone overproduced in the proximal foregut in diabetic patients might counteract the action of insulin, thus inducing insulin resistance and only secondarily hyperinsulinemia.

Collectively, evidence supports the concept that the effect of bariatric surgery on diabetes is mediated by a change in the pattern of secretion of gastrointestinal hormones [116], 
supporting the use of them as therapeutic targets [117-119]. As a first instance, there is a greater insulin sensitivity due to a better $\beta$-cell function including the first phase of insulin secretion [120]. Also, there is restoration of a near-normal, postprandial insulin response soon after RYGBP [121], which is associated with a rise in GLP-1 levels [122]. Even more, ghrelin levels fall after RYGBP [109], resulting in appetite reduction.

It has been proposed that the bypass of the foregut in RYGBP restores normal GIP sensitivity and normalises the GIP levels [111], breaking the "GIP-resistant state," present in T2DM [123].

With the strong evidence published worldwide, surgery has been proven to be superior to medical treatment in terms of maintaining weight loss and altering the natural course of T2DM, which has been considered medically incurable [108, 124]. Despite the obvious risks of surgery [125], the risks of morbid obesity as well as all its associated comorbidities make surgery a viable option in those who are eligible.

\section{The Adipose-Intestinal Missing Link}

In susceptible individuals, chronic exaggerated stimulation of the proximal gut with fat and carbohydrates may induce overproduction of an unknown factor that causes impairment of incretin production and/or action, leading to insufficient or untimely production of insulin, so that glucose intolerance develops.

The bypass of the duodenum and jejunum might avoid a putative hormone overproduction in the proximal foregut in diabetic patients that might counteract the action of insulin, while the early presentation of undigested or incompletely digested food to the ileum may anticipate the production of hormones such as GLP1, further improving insulin action [126]. Moreover, GLP-1 has been implicated in the differentiation of pancreatic exocrine cells toward $\beta$ cells by the Pdx-1 gene transcription stimulation. Indeed, GLP-1 increases the expression of $\beta$-cell-specific genes such as insulin, glucose transporter 2 (GLUT2), and glucokinase in human and rat pancreatic ductal cells transfected with Pdx-1 compared with those transfected with null vector [127].

Carbohydrates are mostly digested to glucose, fructose, and galactose before absorption by the small intestine. Absorption across the brush border and basolateral membranes of enterocytes is mediated by $\mathrm{Na}^{+}$-dependent and -independent membrane proteins. Glucose and galactose transport across the brush border occur by a $\mathrm{Na}^{+}$/glucose (galactose) cotransporter (SGLT1), whereas passive fructose transport is mediated by a uniporter (GLUT5). The passive exit of all three sugars out of the cell across the basolateral membrane occurs through two uniporters (GLUT2 and GLUT5). Mutations in SGLT1 cause a major defect in glucose and galactose absorption (glucose-galactose malabsorption), but mutations in GLUT2 do not appear to disrupt glucose and galactose absorption [128].

Because bariatric surgery with bypass obviates a great area of disaccharidases action, it is expected a reduction in glucose absorption which consequently leads to hyperglycemia improvement. Notwithstanding, a metabolic control would not be registered if there was not a $\beta$-cell recovery.

The common variable in the pathogenesis of GDM and T2DM is the weight gain surpassing recommended BMI. Furthermore, keeping a normal weight is fundamental in the prevention of these pathologies that are cured after a great weight loss coming in the puerperium or with bariatric surgery, respectively. This implies the role of circulating adipose signal acting on the proximal intestine that might inactivate a critical factor for the metabolic homeostasis (mainly insulin effect). SGLT1 or disaccharidases might be two target candidates to be affected by this adipose tissue derived factor.

Tumour necrosis factor $\alpha$ (TNF- $\alpha$ ) expressed in high circulating levels in obesity is a proinflammatory cytokine implicated in the induction of insulin resistance [129]. There is also evidence of TNF- $\alpha$ effects on the $\beta$ cell, which may further contribute to T2DM, although, as this cytokine is expressed in many other diseases without causing T2DM is low the probability to be by itself the adipose-intestinal link of T2DM.

\section{Conclusions}

The combined effects of macronutrients on the predominant gut hormone secretion are still poorly understood. Thus, from a therapeutic perspective, targeting the interaction of appetite signals in the gut offers the potential advantage of being able to manipulate appetite at a site distant from the CNS through endocrine and vagal nerve mechanisms [130].

Finally, future studies will target the identification of a proximal intestinal metabolic molecule, implicated as the cause or cure of T2DM whether activated or not.

\section{References}

[1] K. M. Ramsey, B. Marcheva, A. Kohsaka, and J. Bass, "The clockwork of metabolism," Annual Review of Nutrition, vol. 27, pp. 219-240, 2007.

[2] M. P. Kyithar and S. F. Dinneen, "ACP Journal Club. An intensive lifestyle intervention increased remission from type 2 diabetes in overweight adults," Annals of Internal Medicine, vol. 158, no. 10, article JC4, 2013.

[3] A. De Silva and S. R. Bloom, "Gut hormones and appetite control: a focus on PYY and GLP-1 as therapeutic targets in obesity," Gut and Liver, vol. 6, no. 1, pp. 10-20, 2012.

[4] N. Delzenne, J. Blundell, F. Brouns et al., "Gastrointestinal targets of appetite regulation in humans: ILSI supplement," Obesity Reviews, vol. 11, no. 3, pp. 234-250, 2010.

[5] H. Zheng and H. R. Berthoud, "Eating for pleasure or calories," Current Opinion in Pharmacology, vol. 7, no. 6, pp. 607-612, 2007.

[6] K. H. Johnson, T. D. O’Brien, and P. Westermark, "Newly identified pancreatic protein islet amyloid polypeptide: what is its relationship to diabetes?" Diabetes, vol. 40, no. 3, pp. 310-314, 1991.

[7] J. E. Koda, M. Fineman, T. J. Rink, G. E. Dailey, D. B. Muchmore, and L. G. Linarelli, "Amylin concentrations and glucose control [21]," Lancet, vol. 339, no. 8802, pp. 1179-1180, 1992. 
[8] T. A. Lutz, "Amylinergic control of food intake," Physiology and Behavior, vol. 89, no. 4, pp. 465-471, 2006.

[9] J. E. Morley, J. F. Flood, M. Horowitz, P. M. K. Morley, and M. J. Walter, "Modulation of food intake by peripherally administered amylin," American Journal of Physiology-Regulatory Integrative and Comparative Physiology, vol. 267, no. 1, part 2, pp. R178-R184, 1994.

[10] S. R. Smith, J. E. Blundell, C. Burns et al., "Pramlintide treatment reduces 24 -h caloric intake and meal sizes and improves control of eating in obese subjects: a 6-wk translational research study," American Journal of Physiology-Endocrinology and Metabolism, vol. 293, no. 2, pp. E620-E627, 2007.

[11] P. Y. Wielinga, B. Alder, and T. A. Lutz, "The acute effect of amylin and salmon calcitonin on energy expenditure," Physiology and Behavior, vol. 91, no. 2-3, pp. 212-217, 2007.

[12] D. R. Poyner, P. M. Sexton, I. Marshall et al., "International Union of Pharmacology. XXXII. The mammalian calcitonin gene-related peptides, adrenomedullin, amylin, and calcitonin receptors," Pharmacological Reviews, vol. 54, no. 2, pp. 233-246, 2002.

[13] J. M. Hilton, M. Dowton, S. Houssami, and P. M. Sexton, "Identification of key components in the irreversibility of salmon calcitonin binding to calcitonin receptors," Journal of Endocrinology, vol. 166, no. 1, pp. 213-226, 2000.

[14] T. Riediger, H. A. Schmid, T. A. Lutz, and E. Simon, "Amylin and glucose co-activate area postrema neurons of the rat," Neuroscience Letters, vol. 328, no. 2, pp. 121-124, 2002.

[15] J. P. Lomenick, M. S. Melguizo, S. L. Mitchell, M. L. Summar, and J. W. Anderson, "Effects of meals high in carbohydrate, protein, and fat on ghrelin and peptide YY secretion in prepubertal children," Journal of Clinical Endocrinology and Metabolism, vol. 94, no. 11, pp. 4463-4471, 2009.

[16] N. Germain, B. Galusca, D. Grouselle et al., "Ghrelin and obestatin circadian levels differentiate bingeing-purging from restrictive anorexia nervosa," Journal of Clinical Endocrinology and Metabolism, vol. 95, no. 6, pp. 3057-3062, 2010.

[17] P. J. Tomasik, K. Sztefko, and J. Starzyk, "Entero-insular axis in children with simple obesity," Pediatric Endocrinology, Diabetes and Metabolism, vol. 15, no. 2, pp. 63-69, 2009.

[18] J. G. Santillan-Benitez, H. Mendieta-Zeron, L. M. GomezOlivan et al., "The tetrad BMI, leptin, leptin/adiponectin (L/A) ratio and CA 15-3 are reliable biomarkers of breast cancer," Journal of Clinical Laboratory Analysis, vol. 27, no. 1, pp. 12-20, 2013.

[19] J. M. Beasley, B. A. Ange, C. A. M. Anderson, E. R. Miller III, J. T. Holbrook, and L. J. Appel, "Characteristics associated with fasting appetite hormones (obestatin, Ghrelin, and Leptin)," Obesity, vol. 17, no. 2, pp. 349-354, 2009.

[20] B. Oliván, J. Teixeira, M. Bose et al., "Effect of weight loss by diet or gastric bypass surgery on peptide YY3-36 levels," Annals of Surgery, vol. 249, no. 6, pp. 948-953, 2009.

[21] D. de Luis, D. Pacheco, R. Conde, D. Primo, R. Aller, and O. Izaola, "Basal GLP-1 levels in morbidly obese patients following biliopancreatic diversion surgery," Annals of Nutrition and Metabolism, vol. 61, no. 1, pp. 70-73, 2012.

[22] C. Martins, L. Kjelstrup, I. L. Mostad, and B. Kulseng, "Impact of sustained weight loss achieved through Roux-en-Y gastric bypass or a lifestyle intervention on ghrelin, obestatin, and ghrelin/obestatin ratio in morbidly obese patients," Obesity Surgery, vol. 21, no. 6, pp. 751-758, 2011.

[23] J. Korner, W. Inabnet, G. Febres et al., "Prospective study of gut hormone and metabolic changes after adjustable gastric banding and Roux-en-Y gastric bypass," International Journal of Obesity, vol. 33, no. 7, pp. 786-795, 2009.

[24] B. R. Hill, M. J. de Souza, and N. I. Williams, "Characterization of the diurnal rhythm of peptide YY and its association with energy balance parameters in normal-weight premenopausal women," American Journal of Physiology-Endocrinology and Metabolism, vol. 301, no. 2, pp. E409-E415, 2011.

[25] L. M. Belalcazar, C. M. Ballantyne, W. Lang et al., "Metabolic factors, adipose tissue, and plasminogen activator inhibitor-1 levels in type 2 diabetes: findings from the look AHEAD study," Arteriosclerosis, Thrombosis, and Vascular Biology, vol. 31, no. 7, pp. 1689-1695, 2011.

[26] L. L. Baggio and D. J. Drucker, "Biology of Incretins: GLP-1 and GIP," Gastroenterology, vol. 132, no. 6, pp. 2131-2157, 2007.

[27] U. Cuntz, P. Enck, E. Frühauf et al., "Cholecystokinin revisited: CCK and the hunger trap in anorexia nervosa," PLoS One, vol. 8, no. 1, Article ID e54457, 2013.

[28] H. E. Raybould, J. Glatzle, S. L. Freeman et al., "Detection of macronutrients in the intestinal wall," Autonomic Neuroscience, vol. 125, no. 1-2, pp. 28-33, 2006.

[29] N. Geary, "Endocrine controls of eating: CCK, leptin, and ghrelin," Physiology and Behavior, vol. 81, no. 5, pp. 719-733, 2004.

[30] T. A. L. Brown, M. C. Washington, S. A. Metcalf, and A. I. Sayegh, "The feeding responses evoked by cholecystokinin are mediated by vagus and splanchnic nerves," Peptides, vol. 32, no. 8, pp. 1581-1586, 2011.

[31] R. Gómez, M. Navarro, B. Ferrer et al., "A peripheral mechanism for CB1 cannabinoid receptor-dependent modulation of feeding," Journal of Neuroscience, vol. 22, no. 21, pp. 9612-9617, 2002.

[32] V. Di Marzo, R. Capasso, I. Matias et al., "The role of endocannabinoids in the regulation of gastric emptying: alterations in mice fed a high-fat diet," British Journal of Pharmacology, vol. 153, no. 6, pp. 1272-1280, 2008.

[33] G. Paulino, C. B. De La Serre, T. A. Knotts et al., "Increased expression of receptors for orexigenic factors in nodose ganglion of diet-induced obese rats," American Journal of Physiology-Endocrinology and Metabolism, vol. 296, no. 4, pp. E898-E903, 2009.

[34] A. A. Izzo, F. Piscitelli, R. Capasso et al., "Peripheral endocannabinoid dysregulation in obesity: relation to intestinal motility and energy processing induced by food deprivation and re-feeding," British Journal of Pharmacology, vol. 158, no. 2, pp. 451-461, 2009.

[35] N. L. Cluny, V. K. Vemuri, A. P. Chambers et al., "A novel peripherally restricted cannabinoid receptor antagonist, AM6545, reduces food intake and body weight, but does not cause malaise, in rodents," British Journal of Pharmacology, vol. 161, no. 3, pp. 629-642, 2010.

[36] J. H. Yu and M. S. Kim, "Molecular mechanisms of appetite regulation," Diabetes and Metabolism Journal, vol. 36, no. 6, pp. 391-398, 2012.

[37] M. Kojima, H. Hosoda, Y. Date, M. Nakazato, H. Matsuo, and K. Kangawa, "Ghrelin is a growth-hormone-releasing acylated peptide from stomach," Nature, vol. 402, no. 6762, pp. 656-660, 1999.

[38] G. Burdyga, A. Varro, R. Dimaline, D. G. Thompson, and G. J. Dockray, "Ghrelin receptors in rat and human nodose ganglia: putative role in regulating $\mathrm{CB}-1$ and $\mathrm{MCH}$ receptor abundance," American Journal of Physiology-Gastrointestinal and Liver Physiology, vol. 290, no. 6, pp. G1289-G1297, 2006. 
[39] C. W. Le Roux, M. Patterson, R. P. Vincent, C. Hunt, M. A. Ghatei, and S. R. Bloom, "Postprandial plasma ghrelin is suppressed proportional to meal calorie content in normalweight but not obese subjects," Journal of Clinical Endocrinology and Metabolism, vol. 90, no. 2, pp. 1068-1071, 2005.

[40] D. E. Cummings, D. S. Weigle, R. Scott Frayo et al., "Plasma ghrelin levels after diet-induced weight loss or gastric bypass surgery," New England Journal of Medicine, vol. 346, no. 21, pp. 1623-1630, 2002.

[41] J. J. Hwa, A. B. Fawzi, M. P. Graziano et al., "Leptin increases energy expenditure and selectively promotes fat metabolism in ob/ob mice," American Journal of Physiology-Regulatory Integrative and Comparative Physiology, vol. 272, no. 4, pp. R1204-R1209, 1997.

[42] C. F. Deacon and B. Ahrén, "Physiology of incretins in health and disease," Review of Diabetic Studies, vol. 8, no. 3, pp. 293306, 2011.

[43] F. Lluis, M. Fujimura, G. Gomez, J. A. Salvá, G. H. Greeley Jr., and J. C. Thompson, "Cellular localization, half-life, and secretion of peptide YY," Revista Española de Fisiología, vol. 45, no. 4, pp. 377-384, 1989.

[44] M. J. Dailey and T. H. Moran, "Glucagon-like peptide 1 and appetite," Trends in Endocrinology and Metabolism, vol. 24, no. 2, pp. 85-91, 2013.

[45] A. Mansour, S. Hosseini, B. Larijani, M. Pajouhi, and M. R. Mohajeri-Tehrani, "Nutrients related to GLP1 secretory responses," Nutrition, vol. 29, no. 6, pp. 813-820, 2013.

[46] M. A. Labouesse, U. Stadlbauer, E. Weber, M. Arnold, W. Langhans, and G. Pacheco-López, "Vagal afferents mediate early satiation and prevent flavour avoidance learning in response to intraperitoneally infused exendin-4," Journal of Neuroendocrinology, vol. 24, no. 12, pp. 1505-1516, 2012.

[47] A. S. Rocca and P. L. Brubaker, "Role of the vagus nerve in mediating proximal nutrient-induced glucagon-like peptide-1 secretion," Endocrinology, vol. 140, no. 4, pp. 1687-1694, 1999.

[48] A. Pocai, "Unraveling oxyntomodulin, GLPl's enigmatic brother," Journal of Endocrinology, vol. 215, no. 3, pp. 335-346, 2012.

[49] L. L. Baggio, Q. Huang, T. J. Brown, and D. J. Drucker, “Oxyntomodulin and glucagon-like peptide-1 differentially regulate murine food intake and energy expenditure," Gastroenterology, vol. 127, no. 2, pp. 546-558, 2004.

[50] C. L. Dakin, C. J. Small, R. L. Batterham et al., "Peripheral oxyntomodulin reduces food intake and body weight gain in rats," Endocrinology, vol. 145, no. 6, pp. 2687-2695, 2004.

[51] K. Wynne, A. J. Park, C. J. Small et al., "Subcutaneous oxyntomodulin reduces body weight in overweight and obese subjects: a double-blind, randomized, controlled trial," Diabetes, vol. 54, no. 8, pp. 2390-2395, 2005.

[52] R. L. Batterham and S. R. Bloom, “The gut hormone peptide YY regulates appetite," Annals of the New York Academy of Sciences, vol. 994, pp. 162-168, 2003.

[53] T. E. Adrian, G. L. Ferri, and A. J. Bacarese-Hamilton, "Human distribution and release of a putative new gut hormone, peptide YY," Gastroenterology, vol. 89, no. 5, pp. 1070-1077, 1985.

[54] L. Degen, S. Oesch, M. Casanova et al., "Effect of peptide YY336 on food intake in humans," Gastroenterology, vol. 129, no. 5, pp. 1430-1436, 2005.

[55] P. A. Essah, J. R. Levy, S. N. Sistrun, S. M. Kelly, and J. E. Nestler, "Effect of macronutrient composition on postprandial peptide YY levels," Journal of Clinical Endocrinology and Metabolism, vol. 92, no. 10, pp. 4052-4055, 2007.
[56] N. Helou, O. Obeid, S. T. Azar, and N. Hwalla, "Variation of postprandial PYY3-36 response following ingestion of differing macronutrient meals in obese females," Annals of Nutrition and Metabolism, vol. 52, no. 3, pp. 188-195, 2008.

[57] R. L. Batterham, M. A. Cohen, S. M. Ellis et al., "Inhibition of food intake in obese subjects by peptide YY3-36," New England Journal of Medicine, vol. 349, no. 10, pp. 941-948, 2003.

[58] S. J. Dunmore and J. E. Brown, "The role of adipokines in betacell failure of type 2 diabetes," Journal of Endocrinology, vol. 216, no. 1, pp. T37-T45, 2013.

[59] U. B. Pajvani, X. Du, T. P. Combs et al., "Structure-function studies of the adipocyte-secreted hormone Acrp30/adiponectin: implications for metabolic regulation and bioactivity," Journal of Biological Chemistry, vol. 278, no. 11, pp. 9073-9085, 2003.

[60] N. Ouchi, S. Kihara, Y. Arita et al., "Novel modulator for endothelial adhesion molecules: adipocyte-derived plasma protein adiponectin," Circulation, vol. 100, no. 25, pp. 2473-2476, 1999.

[61] G. Fruhbeck, Peptides in Energy Balance and Obesity, CABI Publishing, Wallingford, UK, 2009.

[62] K. Robinson, J. Prins, and B. Venkatesh, "Clinical review: adiponectin biology and its role in inflammation and critical illness," Critical Care, vol. 15, no. 2, article 221, 2011.

[63] G. Paz-Filho, C. Mastronardi, C. B. Franco, K. B. Wang, M. L. Wong, and J. Licinio, "Leptin: molecular mechanisms, systemic pro-inflammatory effects, and clinical implications," Archivos Brasileiros de Endocrinologia y Metabología, vol. 56, no. 9, pp. 597-607, 2012.

[64] J. G. Santillán Benítez, A. Ordóñez Quiroz, H. Mendieta Zerón, and L. M. Gómez Oliván, "La leptina en la carcinogénesis mamaria vías de señalización," Química Viva, vol. 11, no. 2, pp. 91-111, 2012.

[65] R. Coppari and C. Bjorbaek, "Leptin revisited: its mechanism of action and potential for treating diabetes," Nature Reviews Drug Discovery, vol. 11, no. 9, pp. 692-708, 2012.

[66] S. Margetic, C. Gazzola, G. G. Pegg, and R. A. Hill, "Leptin: a review of its peripheral actions and interactions," International Journal of Obesity, vol. 26, no. 11, pp. 1407-1433, 2002.

[67] E. González-Jiménez, M. J. Aguilar Cordero, C. A. Padilla Lopez, and G. Garcia I, "Monogenic human obesity: role of the leptin-melanocortin system in the regulation of food intake and body weight in humans," Anales del Sistema Sanitario de Navarra, vol. 35, no. 2, pp. 285-293, 2012.

[68] S. G. Bouret, S. H. Bates, S. Chen, M. G. Myers Jr., and R. B. Simerly, "Distinct roles for specific leptin receptor signals in the development of hypothalamic feeding circuits," Journal of Neuroscience, vol. 32, no. 4, pp. 1244-1252, 2012.

[69] Y. Minokoshi, T. Alquier, H. Furukawa et al., "AMP-kinase regulates food intake by responding to hormonal and nutrient signals in the hypothalamus," Nature, vol. 428, no. 6982, pp. 569-574, 2004.

[70] U. Andersson, K. Filipsson, C. R. Abbott et al., "AMP-activated protein kinase plays a role in the control of food intake," Journal of Biological Chemistry, vol. 279, no. 13, pp. 12005-12008, 2004.

[71] C. L. Cox, K. L. Stanhope, J. M. Schwarz et al., "Circulating concentrations of monocyte chemoattractant protein-1, plasminogen activator inhibitor-1, and soluble leukocyte adhesion molecule-1 in overweight/obese men and women consuming fructose- or glucose-sweetened beverages for 10 weeks," Journal of Clinical Endocrinology and Metabolism, vol. 96, no. 12, pp. E2034-E2038, 2011. 
[72] T. A. Lutz, "Control of food intake and energy expenditure by amylin-therapeutic implications," International Journal of Obesity, vol. 33, supplement 1, pp. S24-S27, 2009.

[73] N. M. Neary, C. J. Small, M. R. Druce et al., "Peptide YY3-36 and glucagon-like peptide-17-36 inhibit food intake additively," Endocrinology, vol. 146, no. 12, pp. 5120-5127, 2005.

[74] H. Furuta, "Combination therapy of amylin and leptin," Nihon Rinsho, vol. 70, supplement 3, pp. 740-745, 2012.

[75] V. Bermúdez, F. Bermúdez, and N. Arraiz, "Biología molecular de los transportadores de glucosa: clasificación, estructura y distribución," Archivos Venezolanos de Farmacología y Terapéutica, vol. 26, no. 2, pp. 1-11, 2007.

[76] M. E. Lowe, "Pancreatic triglyceride lipase and colipase: insights into dietary fat digestion," Gastroenterology, vol. 107, no. 5, pp. 1524-1536, 1994.

[77] R. Tundis, M. R. Loizzo, and F. Menichini, "Natural products as alpha-amylase and alpha-glucosidase inhibitors and their hypoglycaemic potential in the treatment of diabetes: an update," Mini Reviews in Medicinal Chemistry, vol. 10, no. 4, pp. 315-331, 2010.

[78] K. Hanhineva, R. Törrönen, I. Bondia-Pons et al., "Impact of dietary polyphenols on carbohydrate metabolism," International Journal of Molecular Sciences, vol. 11, no. 4, pp. 1365-1402, 2010.

[79] P. M. de Sales, P. M. de Souza, L. A. Simeoni, P. D. O. Magalhães, and D. Silveira, " $\alpha$-amylase inhibitors: a review of raw material and isolated compounds from plant source," Journal of Pharmacy and Pharmaceutical Sciences, vol. 15, no. 1, pp. 141-183, 2012.

[80] K. S. Ha, S. H. Jo, B. H. Kang et al., "In vitro and in vivo antihyperglycemic effect of 2 amadori rearrangement compounds, arginyl-fructose and arginyl-fructosyl-glucose," Journal of Food Science, vol. 76, no. 8, pp. H188-H193, 2011.

[81] S. Adisakwattana, P. Jiphimai, P. Prutanopajai, B. Chanathong, S. Sapwarobol, and T. Ariyapitipan, "Evaluation of $\alpha$ glucosidase, $\alpha$-amylase and protein glycation inhibitory activities of edible plants," International Journal of Food Sciences and Nutrition, vol. 61, no. 3, pp. 295-305, 2010.

[82] D. Grussu, D. Stewart, and G. J. McDougall, "Berry polyphenols inhibit $\alpha$-amylase in vitro: identifying active components in rowanberry and raspberry," Journal of Agricultural and Food Chemistry, vol. 59, no. 6, pp. 2324-2331, 2011.

[83] S. Akkarachiyasit, S. Yibchok-Anun, S. Wacharasindhu, and S. Adisakwattana, "In vitro inhibitory effects of cyandin-3rutinoside on pancreatic $\alpha$-amylase and its combined effect with acarbose," Molecules, vol. 16, no. 3, pp. 2075-2083, 2011.

[84] S. Adisakwattana, O. Lerdsuwankij, U. Poputtachai, A. Minipun, and C. Suparpprom, "Inhibitory activity of cinnamon bark species and their combination effect with acarbose against Intestinal $\alpha$-glucosidase and Pancreatic $\alpha$-amylase," Plant Foods for Human Nutrition, vol. 66, no. 2, pp. 143-148, 2011.

[85] L. Gómez, E. Molinar-Toribio, M. A. Calvo-Torras et al., "DFagomine lowers postprandial blood glucose and modulates bacterial adhesion," British Journal of Nutrition, vol. 107, no. 12, pp. 1739-1746, 2012.

[86] T. Matsui, S. Ebuchi, M. Kobayashi et al., "Anti-hyperglycemic effect of diacylated anthocyanin derived from Ipomoea batatas cultivar ayamurasaki can be achieved through the $\alpha$-glucosidase inhibitory action," Journal of Agricultural and Food Chemistry, vol. 50, no. 25, pp. 7244-7248, 2002.

[87] S. Adisakwattana, P. Charoenlertkul, and S. Yibchok-Anun, " $\alpha$ glucosidase inhibitory activity of cyanidin-3-galactoside and synergistic effect with acarbose," Journal of Enzyme Inhibition and Medicinal Chemistry, vol. 24, no. 1, pp. 65-69, 2009.

[88] K. M. Ali, K. Chatterjee, D. De, K. Jana, T. K. Bera, and D. Ghosh, "Inhibitory effect of hydro-methanolic extract of seed of Holarrhena antidysenterica on alpha-glucosidase activity and postprandial blood glucose level in normoglycemic rat," Journal of Ethnopharmacology, vol. 135, no. 1, pp. 194-196, 2011.

[89] H. W. Ryu, J. K. Cho, M. J. Curtis-Long et al., “ $\alpha$-Glucosidase inhibition and antihyperglycemic activity of prenylated xanthones from Garcinia mangostana," Phytochemistry, vol. 72, no. 17, pp. 2148-2154, 2011.

[90] C. H. Park, J. S. Noh, T. Tanaka, K. Uebaba, E. J. Cho, and T. Yokozawa, "The effects of corni fructus extract and its fractions against $\alpha$-glucosidase inhibitory activities in vitro and sucrose tolerance in normal rats," American Journal of Chinese Medicine, vol. 39, no. 2, pp. 367-380, 2011.

[91] H. Sugiyama, Y. Akazome, T. Shoji et al., "Oligomeric procyanidins in apple polyphenol are main active components for inhibition of pancreatic lipase and triglyceride absorption," Journal of Agricultural and Food Chemistry, vol. 55, no. 11, pp. 4604-4609, 2007.

[92] N. Ikarashi, R. Takeda, K. Ito, W. Ochiai, and K. Sugiyama, "The inhibition of lipase and glucosidase activities by acacia polyphenol," Evidence-Based Complementary and Alternative Medicine, vol. 2011, Article ID 272075, 8 pages, 2011.

[93] B. Klijs, S. J. Otto, R. J. Heine, Y. van der Graaf, J. J. Lous, and H. J. de Koning, "Screening for type 2 diabetes in a high-risk population: study design and feasibility of a population-based randomized controlled trial," BMC Public Health, vol. 12, article 671, 2012.

[94] A. Schienkiewitz, G. B. Mensink, and C. Scheidt-Nave, "Comorbidity of overweight and obesity in a nationally representative sample of German adults aged 18-79 years," BMC Public Health, vol. 12, article 658, 2012.

[95] S. H. Kwak, S. H. Kim, Y. M. Cho et al., "A genome-wide association study of gestational diabetes mellitus in Korean women," Diabetes, vol. 61, no. 2, pp. 531-541, 2012.

[96] E. Oteng-Ntim, R. Varma, H. Croker, L. Poston, and P. Doyle, "Lifestyle interventions for overweight and obese pregnant women to improve pregnancy outcome: systematic review and meta-analysis," BMC Medicine, vol. 10, article 47, 2012.

[97] X. Pi-Sunyer, G. Blackburn, F. L. Brancati et al., "Reduction in weight and cardiovascular disease risk factors in individuals with type 2 diabetes: one-year results of the look AHEAD trial," Diabetes Care, vol. 30, no. 6, pp. 1374-1383, 2007.

[98] S. Klein, N. F. Sheard, X. Pi-Sunyer et al., "Weight management through lifestyle modification for the prevention and management of type 2 diabetes: rationale and strategies-a statement of the American Diabetes Association, the North American Association for the Study of Obesity, and the American Society for Clinical Nutrition," Diabetes Care, vol. 27, no. 8, pp. 20672073, 2004.

[99] S. Camastra, M. Manco, A. Mari et al., “ $\beta$-cell function in morbidly obese subjects during free living: long-term effects of weight loss," Diabetes, vol. 54, no. 8, pp. 2382-2389, 2005.

[100] K. S. Polonsky, B. Gumbiner, D. Ostrega, K. Griver, H. Tager, and R. R. Henry, "Alterations in immunoreactive proinsulin and insulin clearance induced by weight loss in NIDDM," Diabetes, vol. 43, no. 7, pp. 871-877, 1994. 
[101] J. S. Garrow, "Treatment of morbid obesity by nonsurgical means: diet, drugs, behavior modification, exercise," Gastroenterology Clinics of North America, vol. 16, no. 3, pp. 443-449, 1987.

[102] B. Geloneze and J. C. Pareja, "Does bariatric surgery cure the metabolic syndrome?" Arquivos Brasileiros de Endocrinologia e Metabologia, vol. 50, no. 2, pp. 400-407, 2006.

[103] W. J. Pories, K. G. MacDonald Jr., E. J. Morgan et al., "Surgical treatment of obesity and its effect on diabetes: 10-y follow-up," American Journal of Clinical Nutrition, vol. 55, no. 2, pp. 582S585S, 1992.

[104] L. Sjöström, A. K. Lindroos, M. Peltonen et al., "Lifestyle, diabetes, and cardiovascular risk factors 10 years after bariatric surgery," New England Journal of Medicine, vol. 351, no. 26, pp. 2683-2693, 2004.

[105] H. Buchwald, R. Estok, K. Fahrbach et al., "Weight and type 2 diabetes after bariatric surgery: systematic review and metaanalysis," American Journal of Medicine, vol. 122, no. 3, pp. 248256, 2009.

[106] P. R. Schauer, B. Burguera, S. Ikramuddin et al., "Effect of laparoscopic Roux-En Y gastric bypass on type 2 diabetes mellitus," Annals of Surgery, vol. 238, no. 4, pp. 467-485, 2003.

[107] H. J. Sugerman, L. G. Wolfe, D. A. Sica et al., "Diabetes and hypertension in severe obesity and effects of gastric bypassinduced weight loss," Annals of Surgery, vol. 237, no. 6, pp. 751756, 2003.

[108] D. M. Nathan, "Initial management of glycemia in type 2 diabetes mellitus," New England Journal of Medicine, vol. 347, no. 17, pp. 1342-1349, 2002.

[109] D. E. Cummings, D. S. Weigle, R. S. Frayo et al., "Plasma ghrelin levels after diet-induced weight loss or gastric bypass surgery," New England Journal of Medicine, vol. 346, no. 21, pp. 1623-1630, 2002.

[110] F. Rubino, "Is type 2 diabetes an operable intestinal disease? A provocative yet reasonable hypothesis," Diabetes care, vol. 31, supplement 2, pp. S290-S296, 2008.

[111] M. S. Hickey, W. J. Pories, K. G. MacDonald Jr. et al., "A new paradigm for type 2 diabetes mellitus: could it be a disease of the foregut?" Annals of Surgery, vol. 227, no. 5, pp. 637-644, 1998.

[112] F. Rubino, M. Gagner, P. Gentileschi et al., "The early effect of the Roux-en-Y gastric bypass on hormones involved in body weight regulation and glucose metabolism," Annals of Surgery, vol. 240, no. 2, pp. 236-242, 2004.

[113] B. Oliván, J. Teixeira, M. Bose et al., "Effect of weight loss by diet or gastric bypass surgery on peptide YY3-36 levels," Annals of Surgery, vol. 249, no. 6, pp. 948-953, 2009.

[114] R. J. Colman, R. M. Anderson, S. C. Johnson et al., "Caloric restriction delays disease onset and mortality in rhesus monkeys," Science, vol. 325, no. 5937, pp. 201-204, 2009.

[115] W. J. Pories and R. J. Albrecht, "Etiology of type II diabetes mellitus: role of the foregut," World Journal of Surgery, vol. 25, no. 4, pp. 527-531, 2001.

[116] I. Valverde, J. Puente, A. Martín-Duce et al., "Changes in glucagon-like peptide-1 (GLP-1) secretion after biliopancreatic diversion or vertical banded gastroplasty in obese subjects," Obesity Surgery, vol. 15, no. 3, pp. 387-397, 2005.

[117] F. Rubino, M. Gagner, P. Gentileschi et al., "The early effect of the Roux-en-Y gastric bypass on hormones involved in body weight regulation and glucose metabolism," Annals of Surgery, vol. 240, no. 2, pp. 236-242, 2004.
[118] H. Mendieta-Zerón, Á. Larrad-Jiménez, M. A. Burrell et al., "Biliopancreatic diversion induces villi elongation and cholecystokinin and ghrelin increase," Diabetes and Metabolic Syndrome: Clinical Research and Reviews, vol. 5, no. 2, pp. 66-70, 2012.

[119] Y. Falkén, P. M. Hellström, J. J. Holst, and E. Näslund, "Changes in glucose homeostasis after Roux-en-Y gastric bypass surgery for obesity at day three, two months, and one year after surgery: role of gut peptides," Journal of Clinical Endocrinology and Metabolism, vol. 96, no. 7, pp. 2227-2235, 2011.

[120] E. V. Polyzogopoulou, F. Kalfarentzos, A. G. Vagenakis, and T. K. Alexandrides, "Restoration of euglycemia and normal acute insulin response to glucose in obese subjects with type 2 diabetes following bariatric surgery," Diabetes, vol. 52, no. 5, pp. 1098-1103, 2003.

[121] B. Laferrère, S. Heshka, K. Wang et al., "Incretin levels and effect are markedly enhanced 1 month after Roux-en-Y gastric bypass surgery in obese patients with type 2 diabetes," Diabetes Care, vol. 30, no. 7, pp. 1709-1716, 2007.

[122] J. A. Cases, I. Gabriely, X. H. Ma et al., "Physiological increase in plasma leptin markedly inhibits insulin secretion in vivo," Diabetes, vol. 50, no. 2, pp. 348-352, 2001.

[123] S. Schenk, M. Saberi, and J. M. Olefsky, "Insulin sensitivity: modulation by nutrients and inflammation," Journal of Clinical Investigation, vol. 118, no. 9, pp. 2992-3002, 2008.

[124] C. D. Sjöström, L. Lissner, H. Wedel, and L. Sjöström, "Reduction in incidence of diabetes, hypertension and lipid disturbances after intentional weight loss induced by bariatric surgery: the SOS intervention study," Obesity Research, vol. 7, no. 5, pp. 477-484, 1999.

[125] W. O. Griffen Jr., B. A. Bivins, R. M. Bell, and K. A. Jackson, "Gastric bypass for morbid obesity," World Journal of Surgery, vol. 5, no. 6, pp. 817-822, 1981.

[126] F. Rubino and M. Gagner, "Potential of surgery for curing type 2 diabetes mellitus," Annals of Surgery, vol. 236, no. 5, pp. 554-559, 2002.

[127] H. Hui, C. Wright, and R. Perfetti, "Glucagon-like peptide 1 induces differentiation of islet duodenal homeobox-1-positive pancreatic ductal cells into insulin-secreting cells," Diabetes, vol. 50, no. 4, pp. 785-796, 2001.

[128] E. M. Wright, M. G. Martín, and E. Turk, "Intestinal absorption in health and disease-sugars," Bailliere's Best Practice and Research in Clinical Gastroenterology, vol. 17, no. 6, pp. 943-956, 2003.

[129] G. S. Hotamisligil, "Mechanisms of TNF- $\alpha$-induced insulin resistance," Experimental and Clinical Endocrinology and Diabetes, vol. 107, no. 2, pp. 119-125, 1999.

[130] O. B. Chaudhri, K. Wynne, and S. R. Bloom, "Can gut hormones control appetite and prevent obesity?" Diabetes care, vol. 31, supplement 2, pp. S284-S289, 2008. 


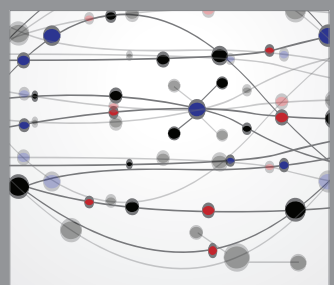

The Scientific World Journal
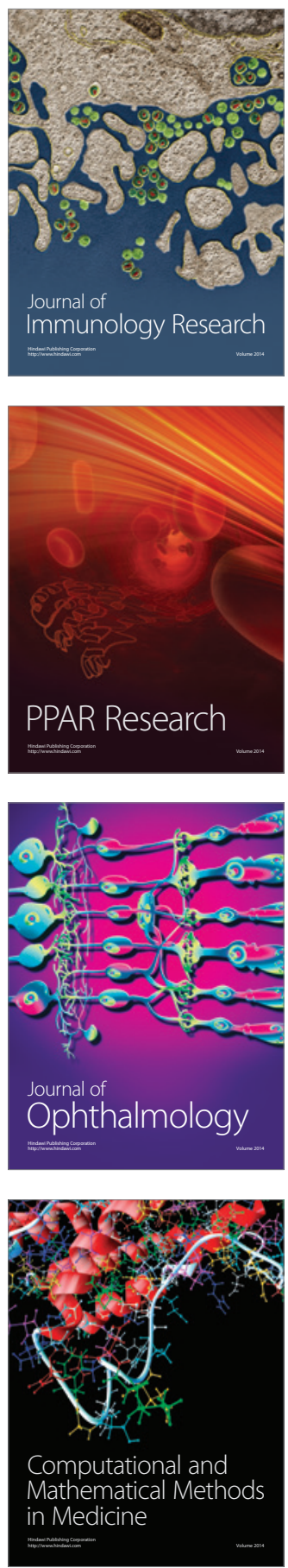

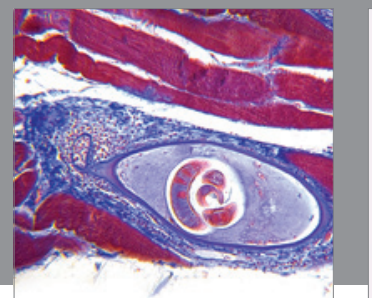

Gastroenterology

Research and Practice
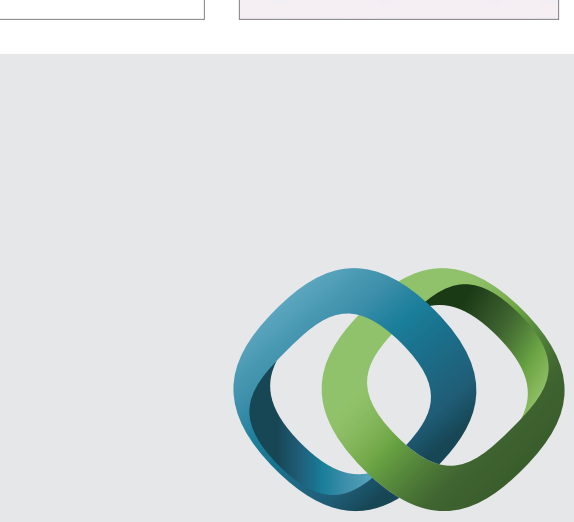

\section{Hindawi}

Submit your manuscripts at

http://www.hindawi.com
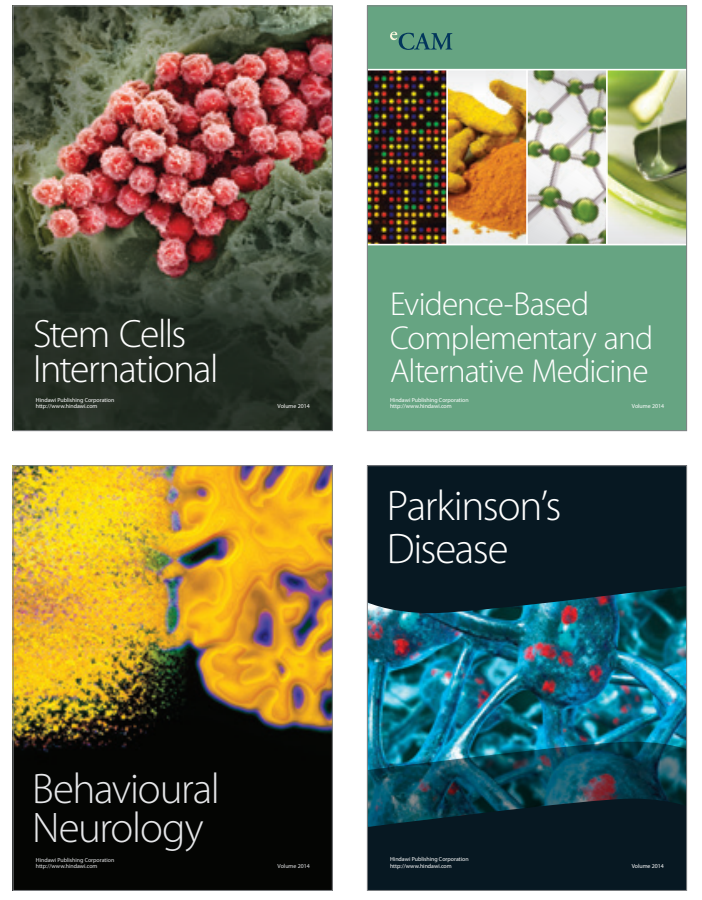
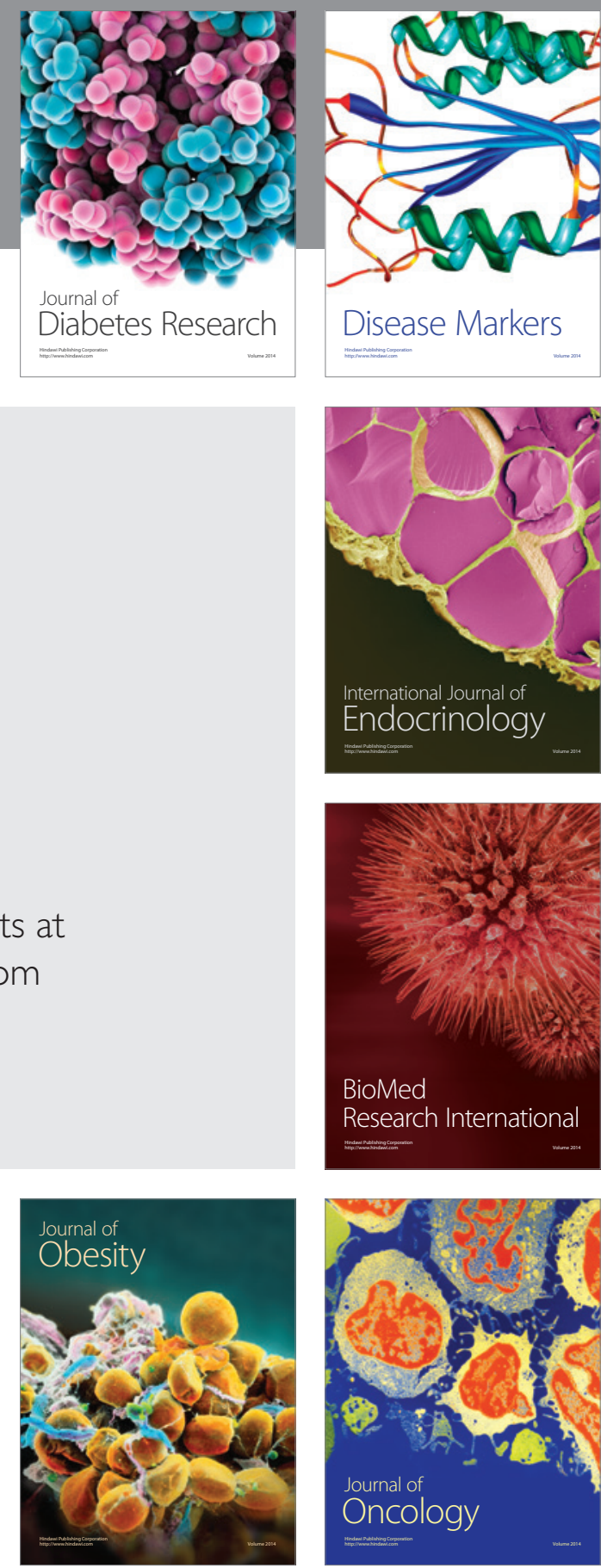

Disease Markers
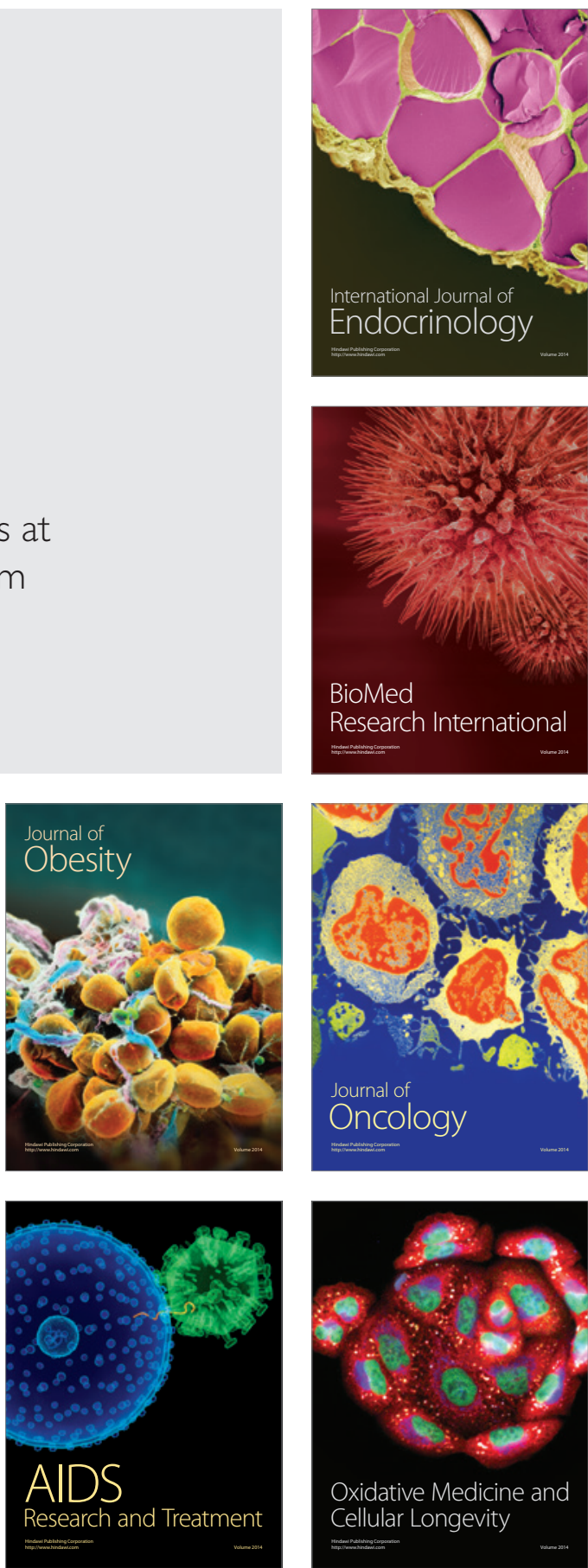